\title{
Practical Asymmetric Preparation of Azetidine-2-carboxylic acid
}

\author{
Francois Couty, ${ }^{*}$ Gwilherm Evano, ${ }^{*}$ Monica Vargas-Sanchez and Gloria Bouzas
}

Laboratoire SIRCOB, UMR CNRS 8086, Université de Versailles Saint Quentin en Yvelines, 45 avenue des Etats-Unis, 78035 Versailles Cedex, France

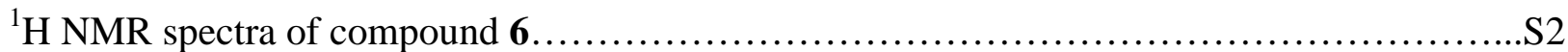

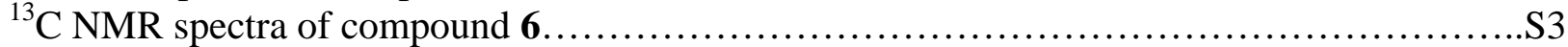

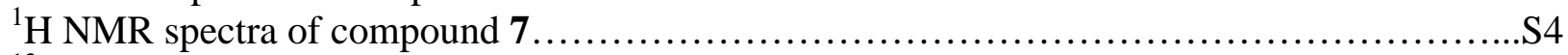

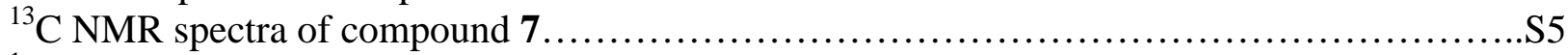

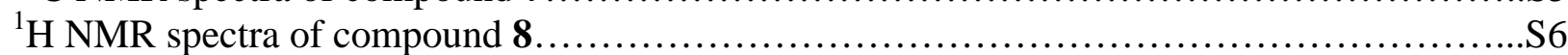

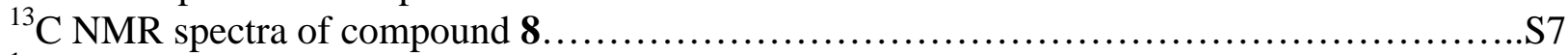

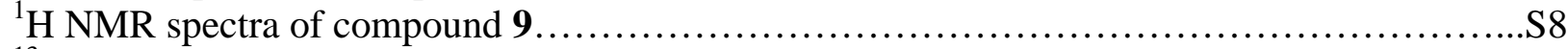

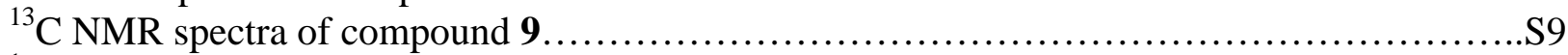

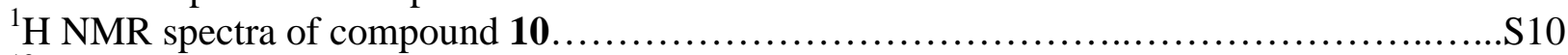

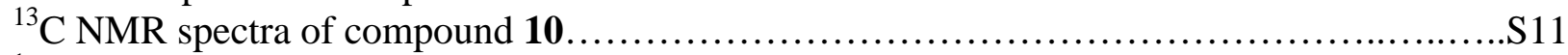

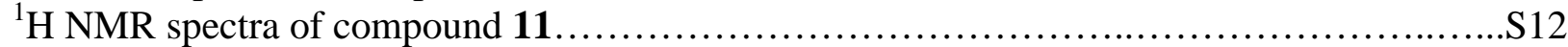

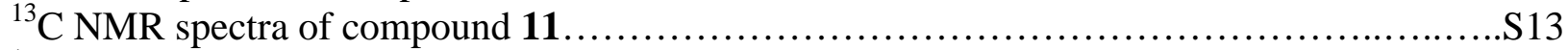

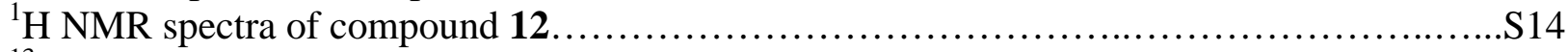

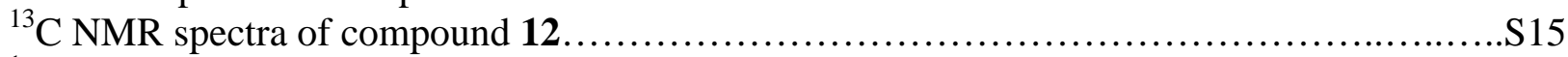

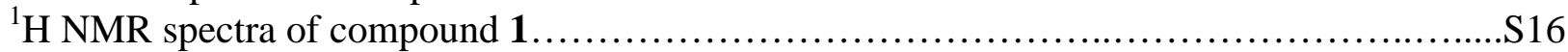

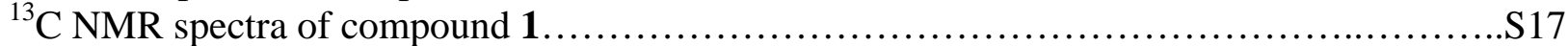

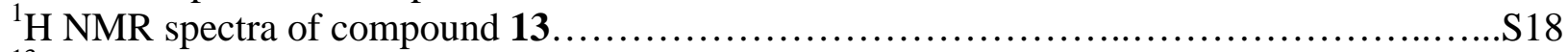

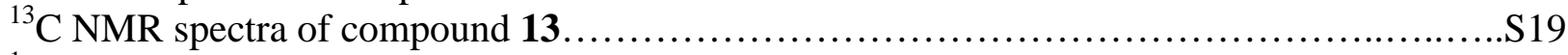

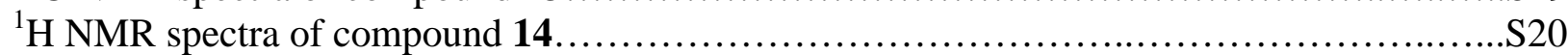

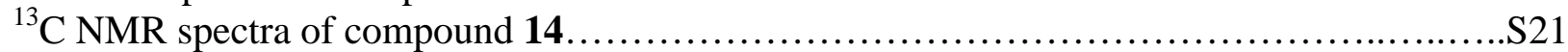

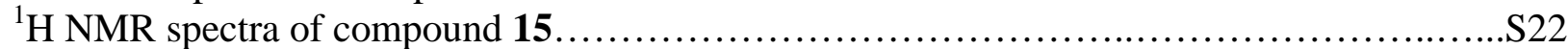

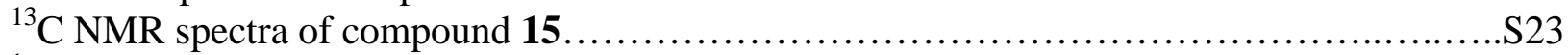

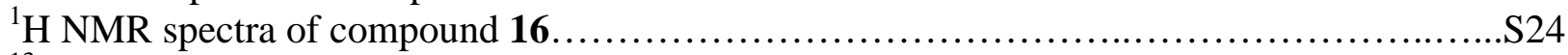

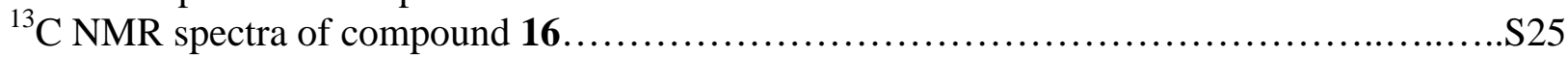



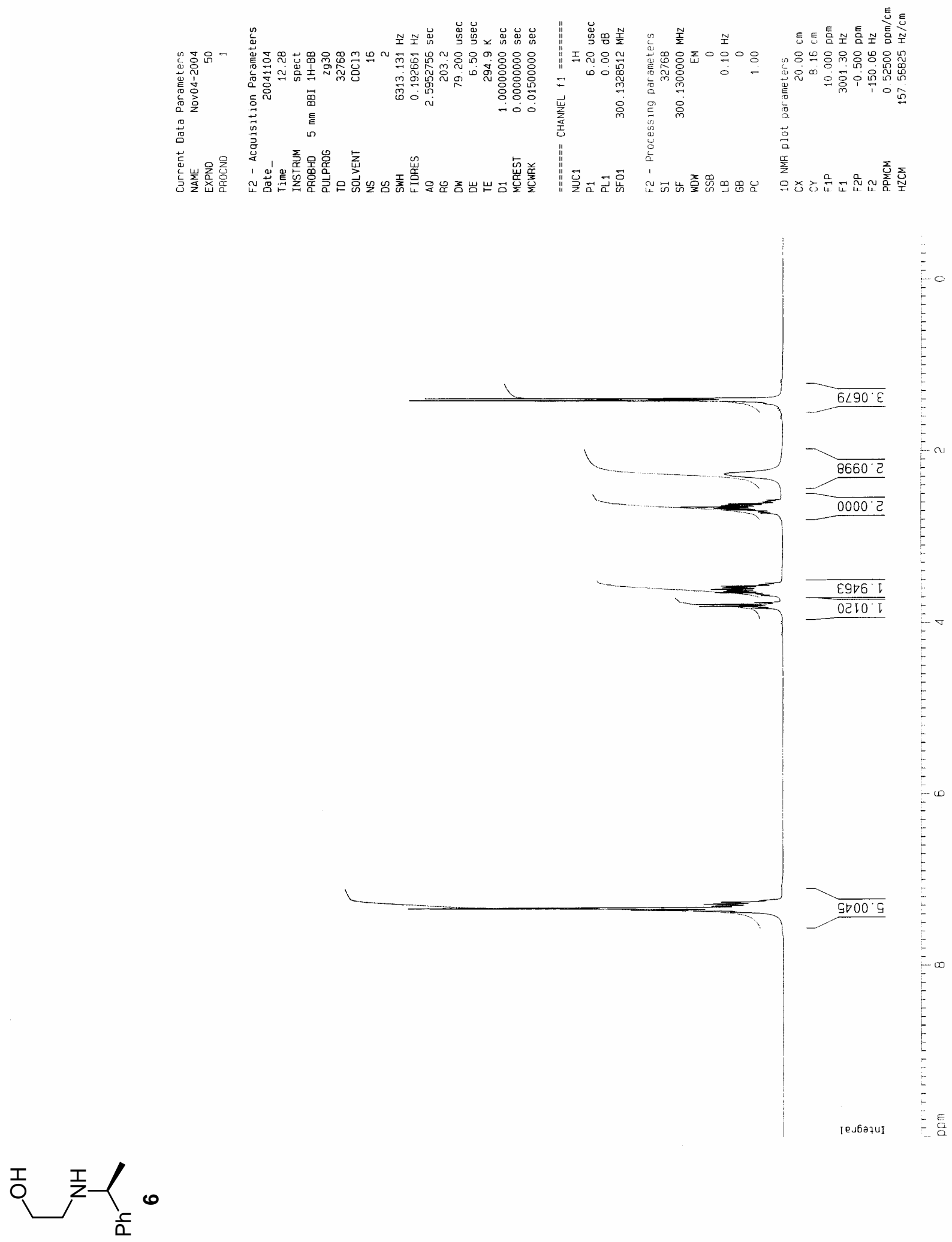

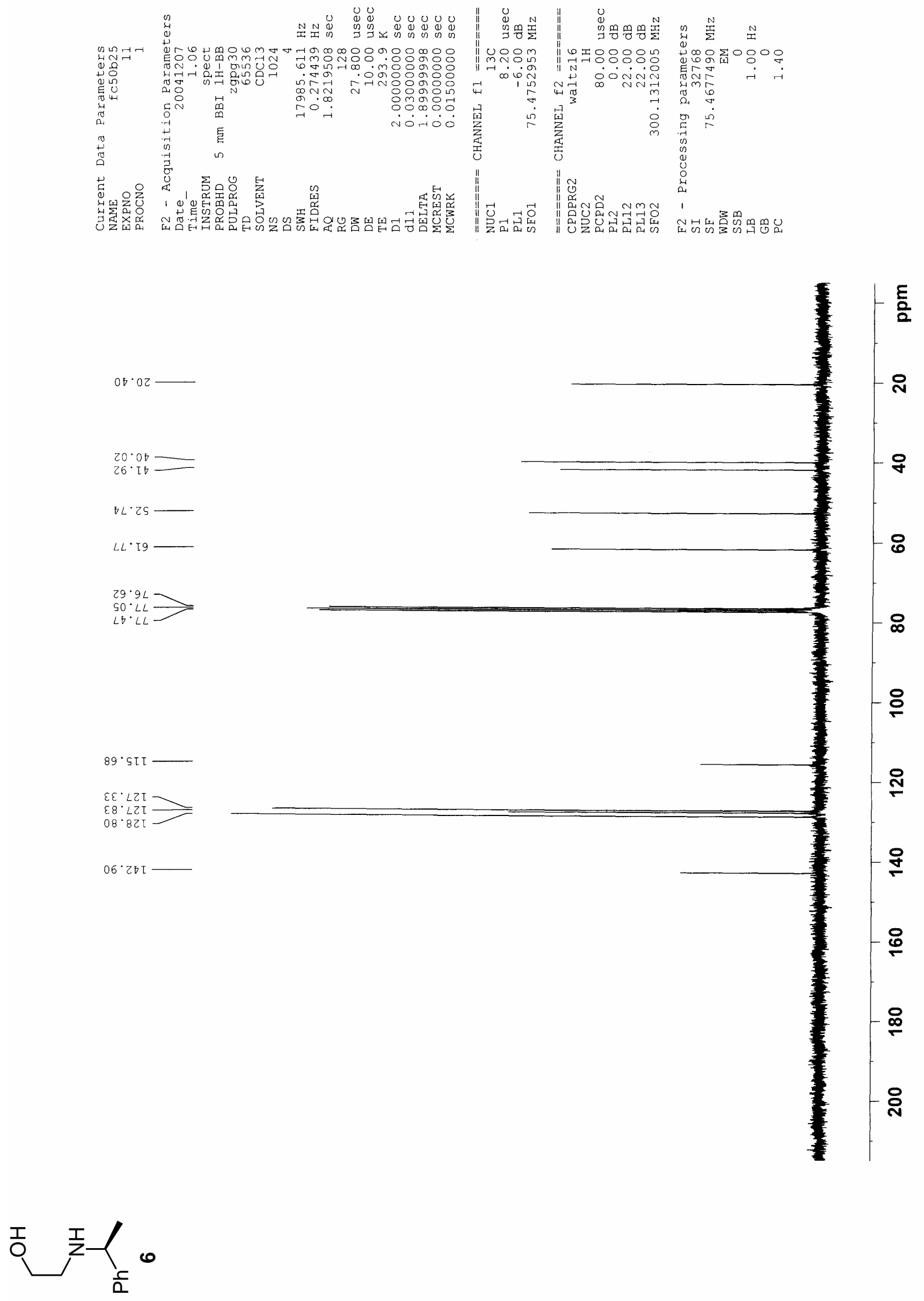

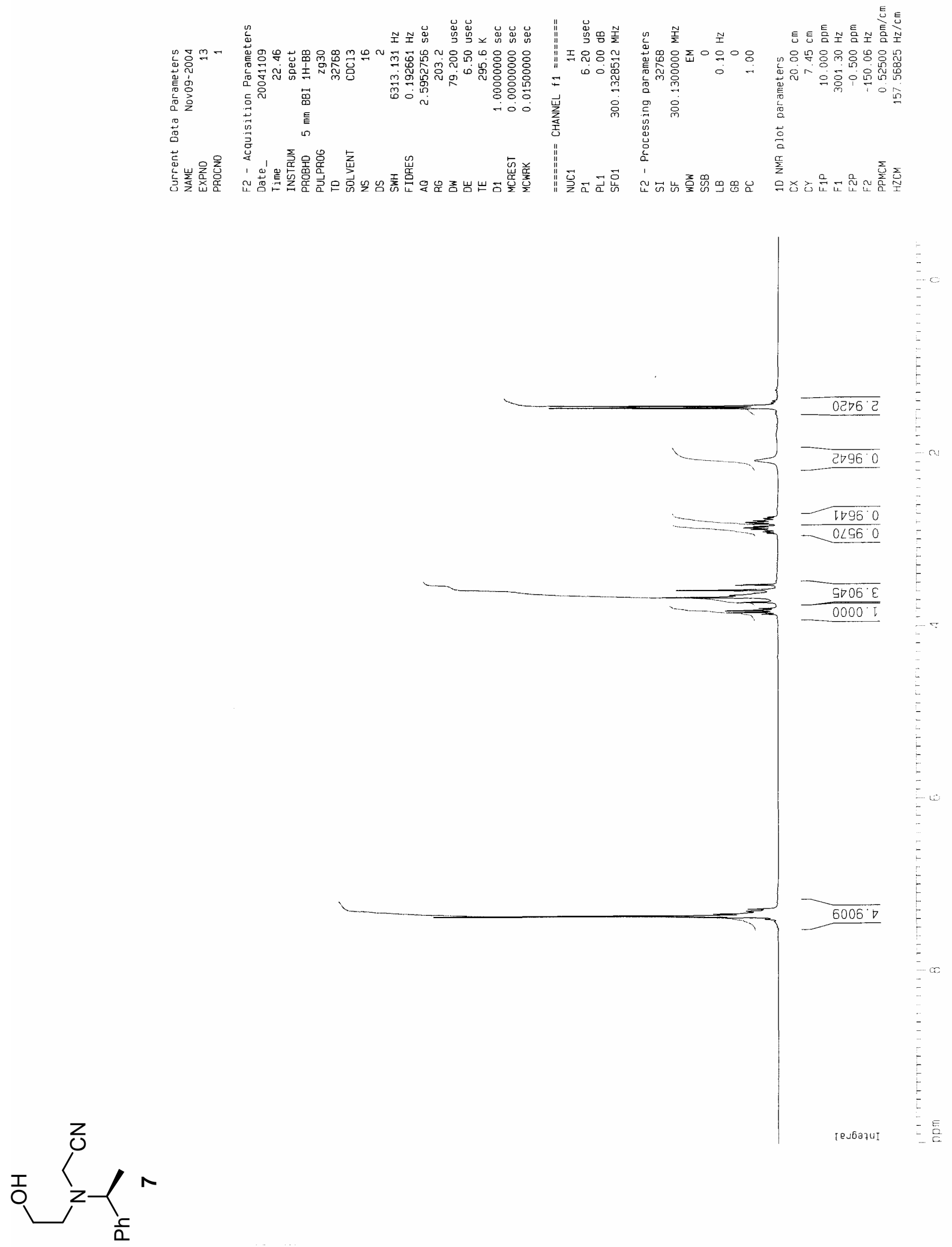


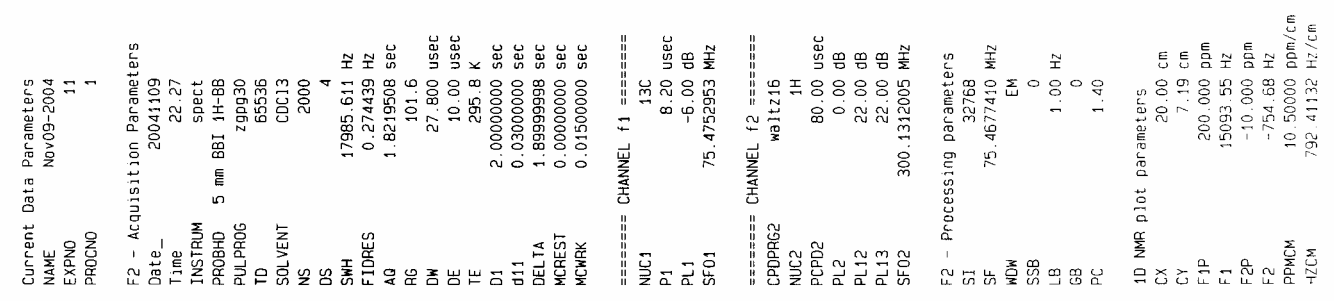

es

$90 \mathrm{~s}$

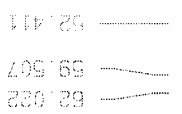

$2320-3$

42
$40+2$

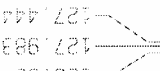

$10680 . .$.

$\underbrace{1} \sum_{\frac{c}{a}}^{2}$

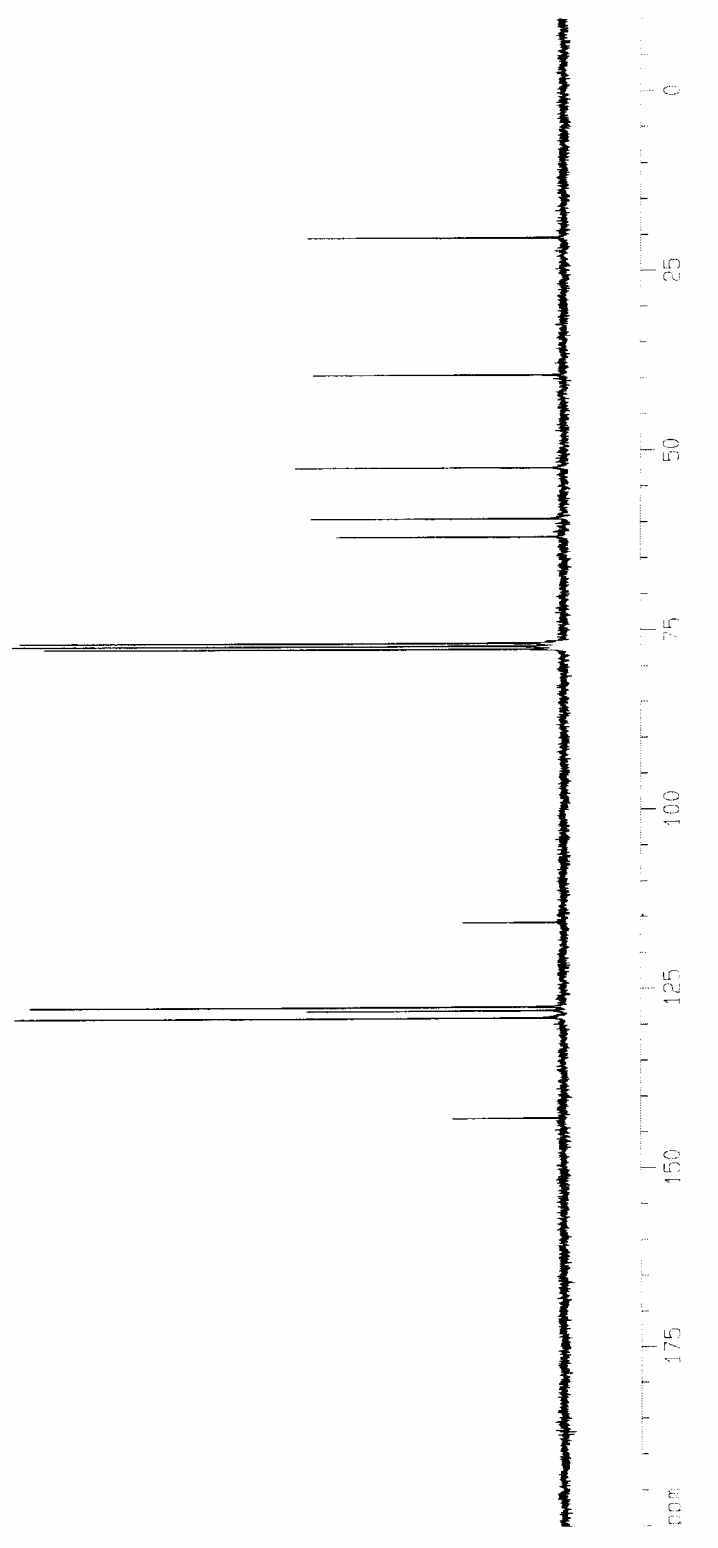



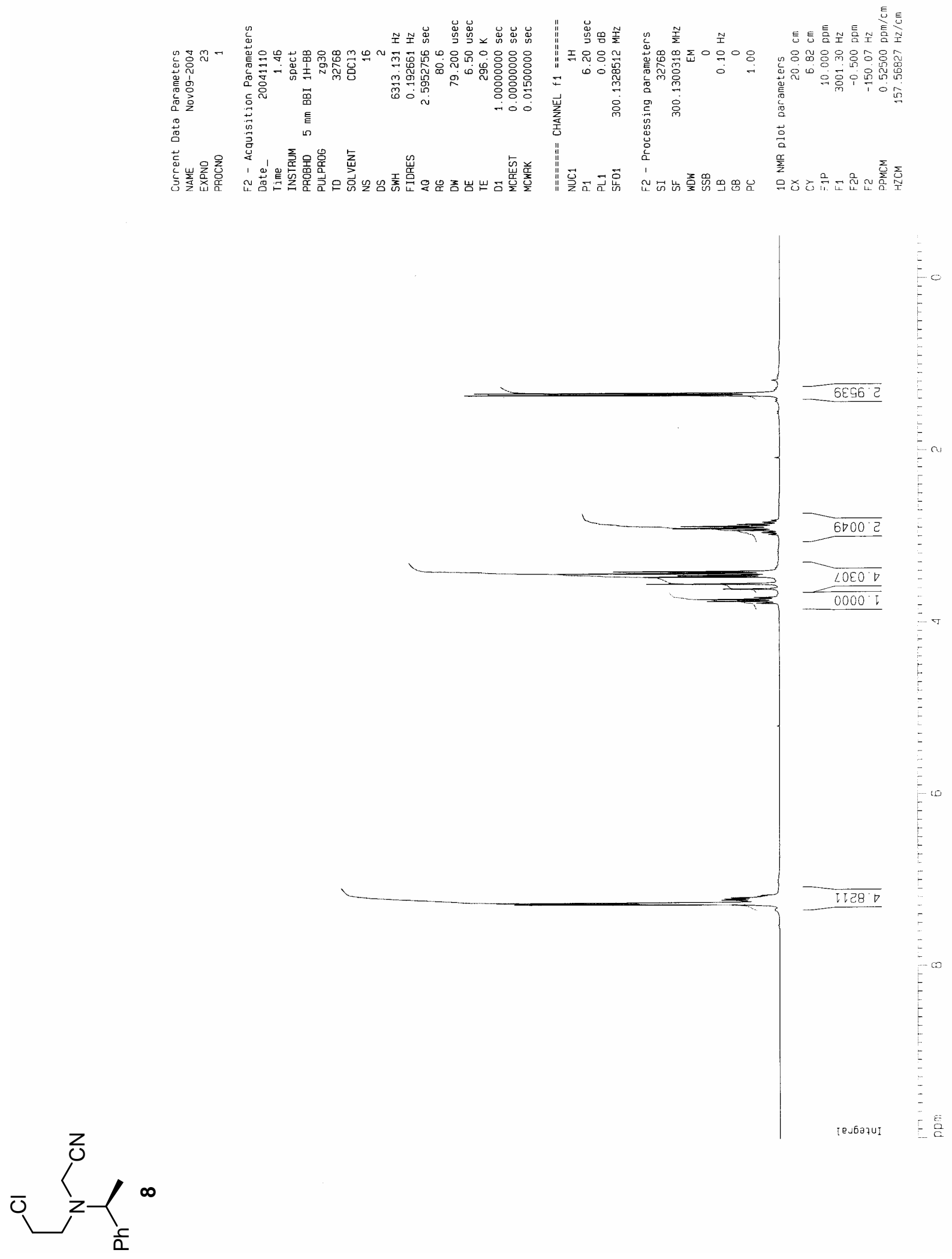


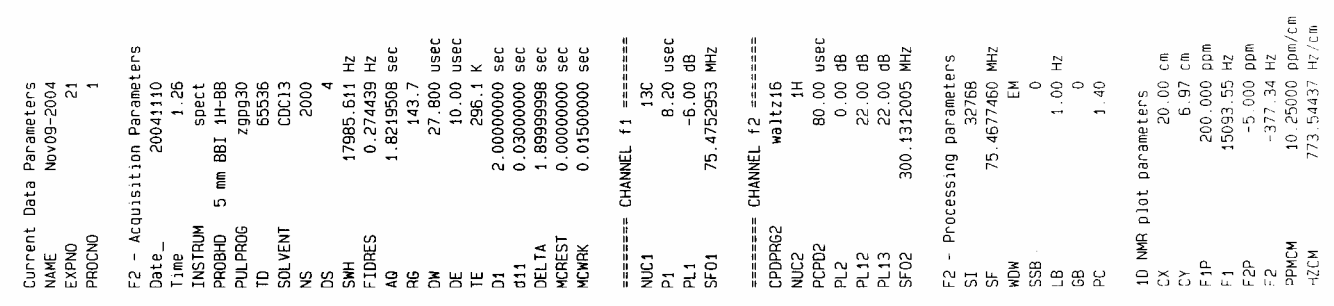

sed os.-
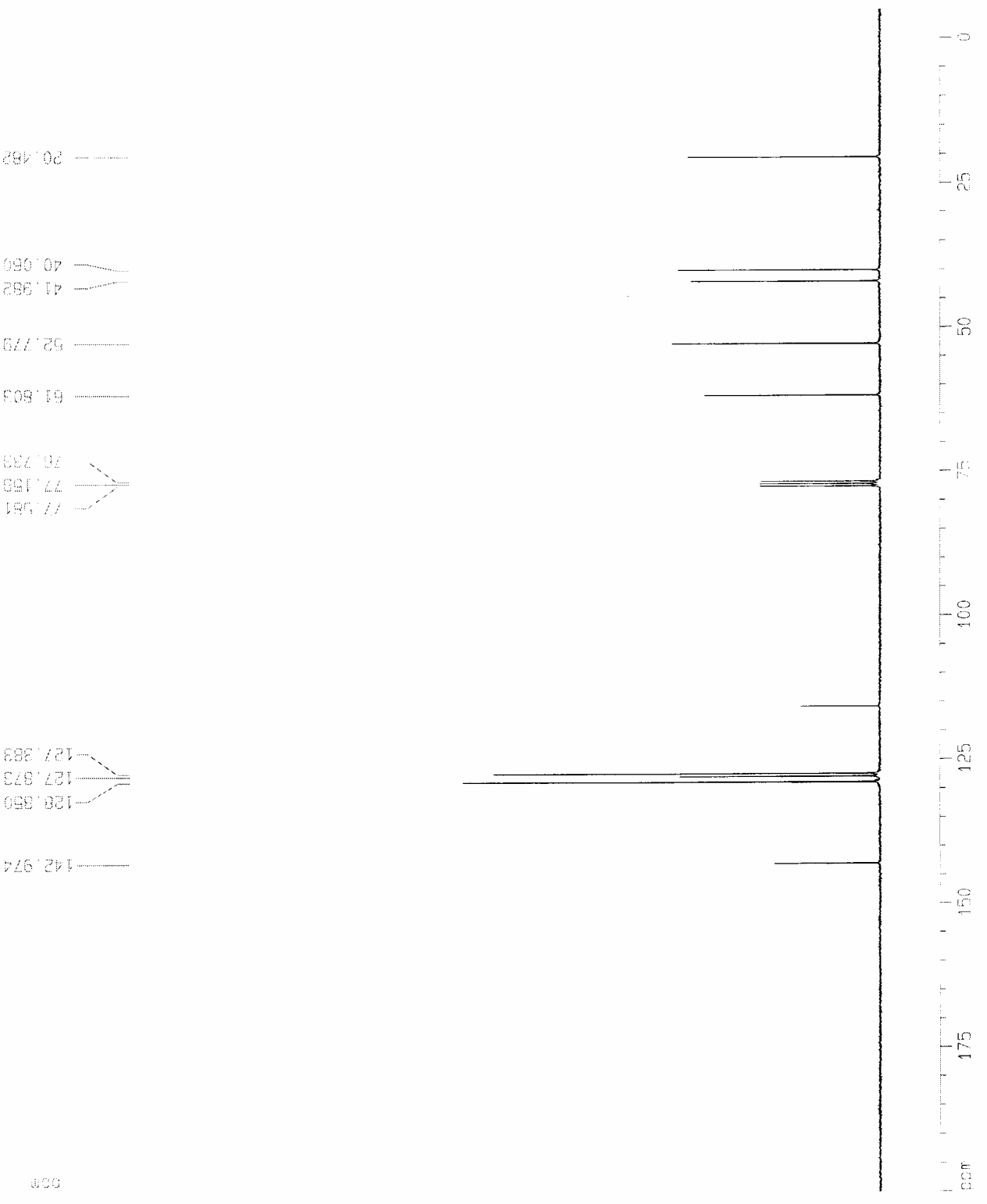

os:

ais 25

$509 \cdot 9$

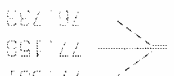

es:

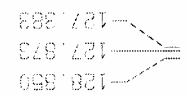

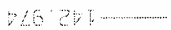

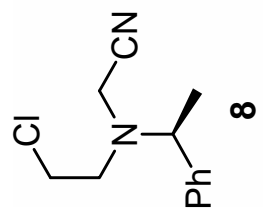



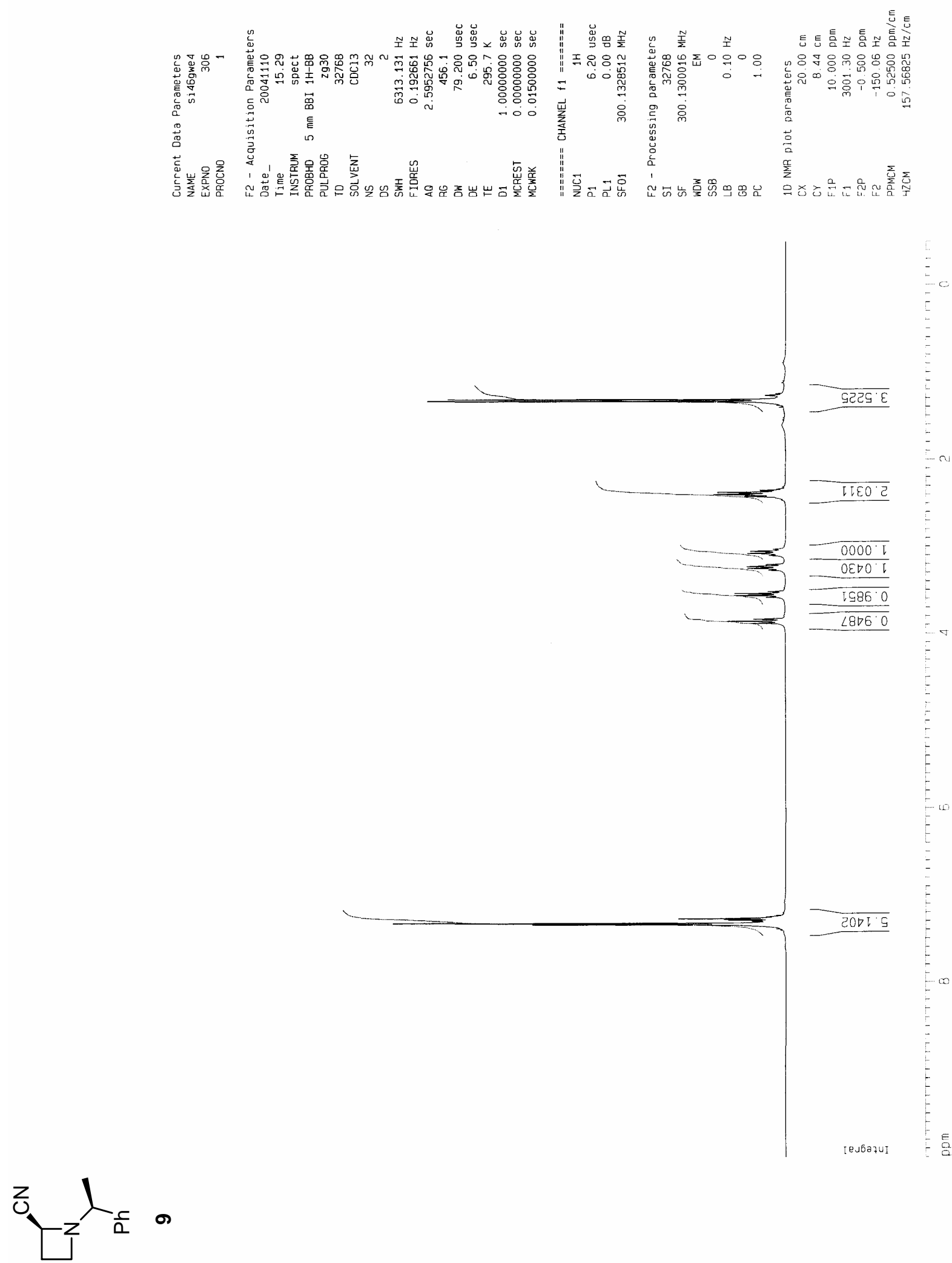

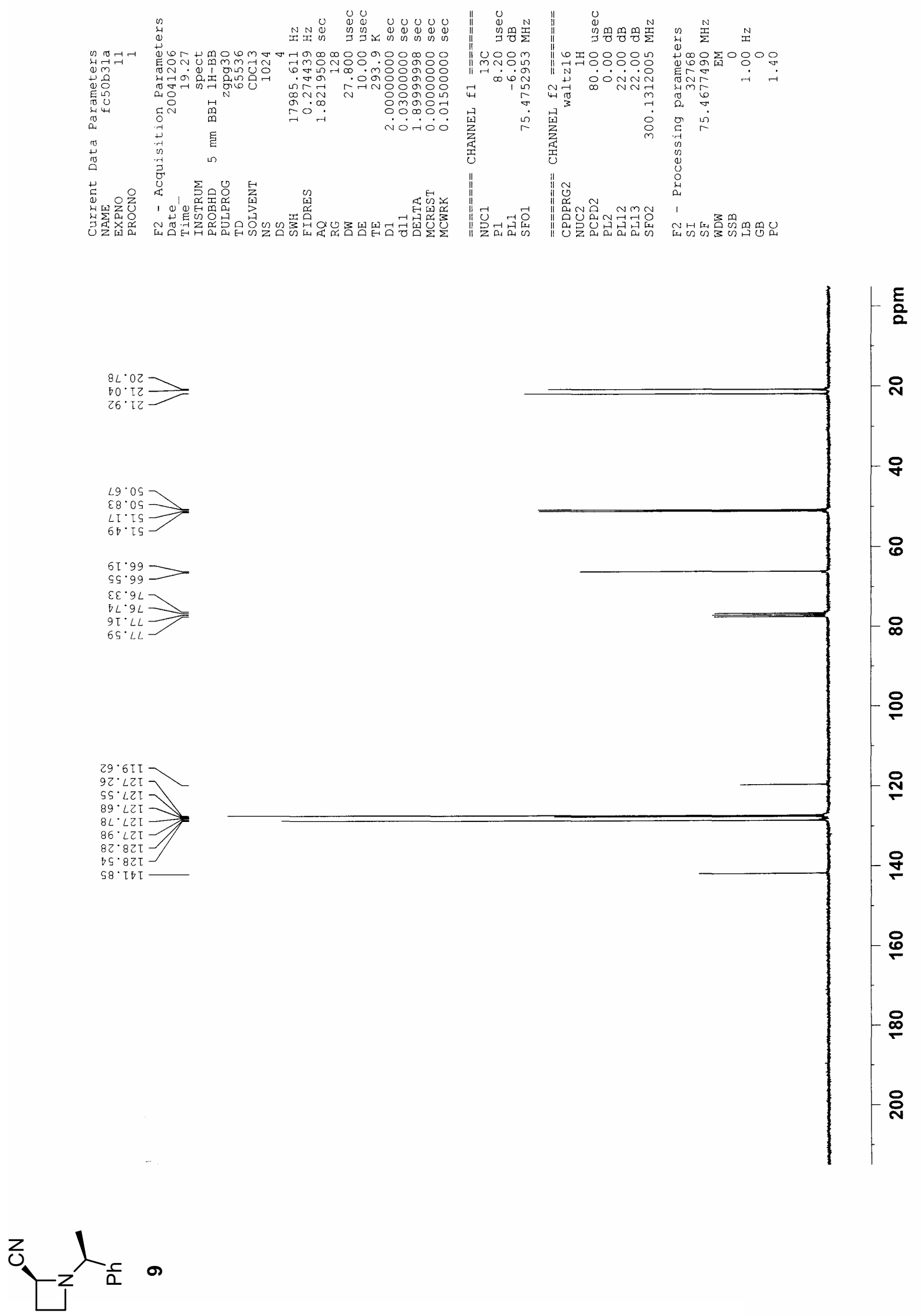

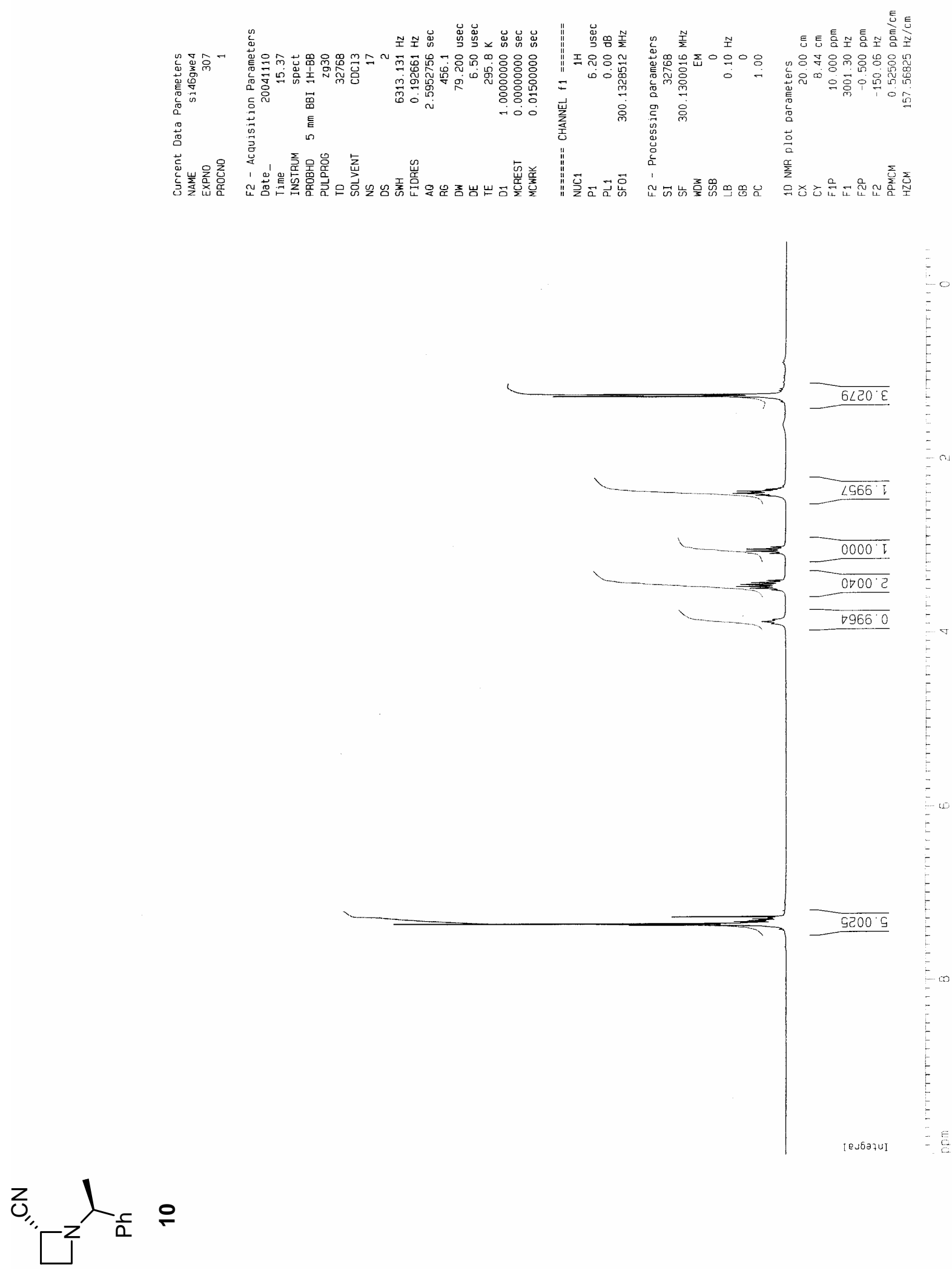

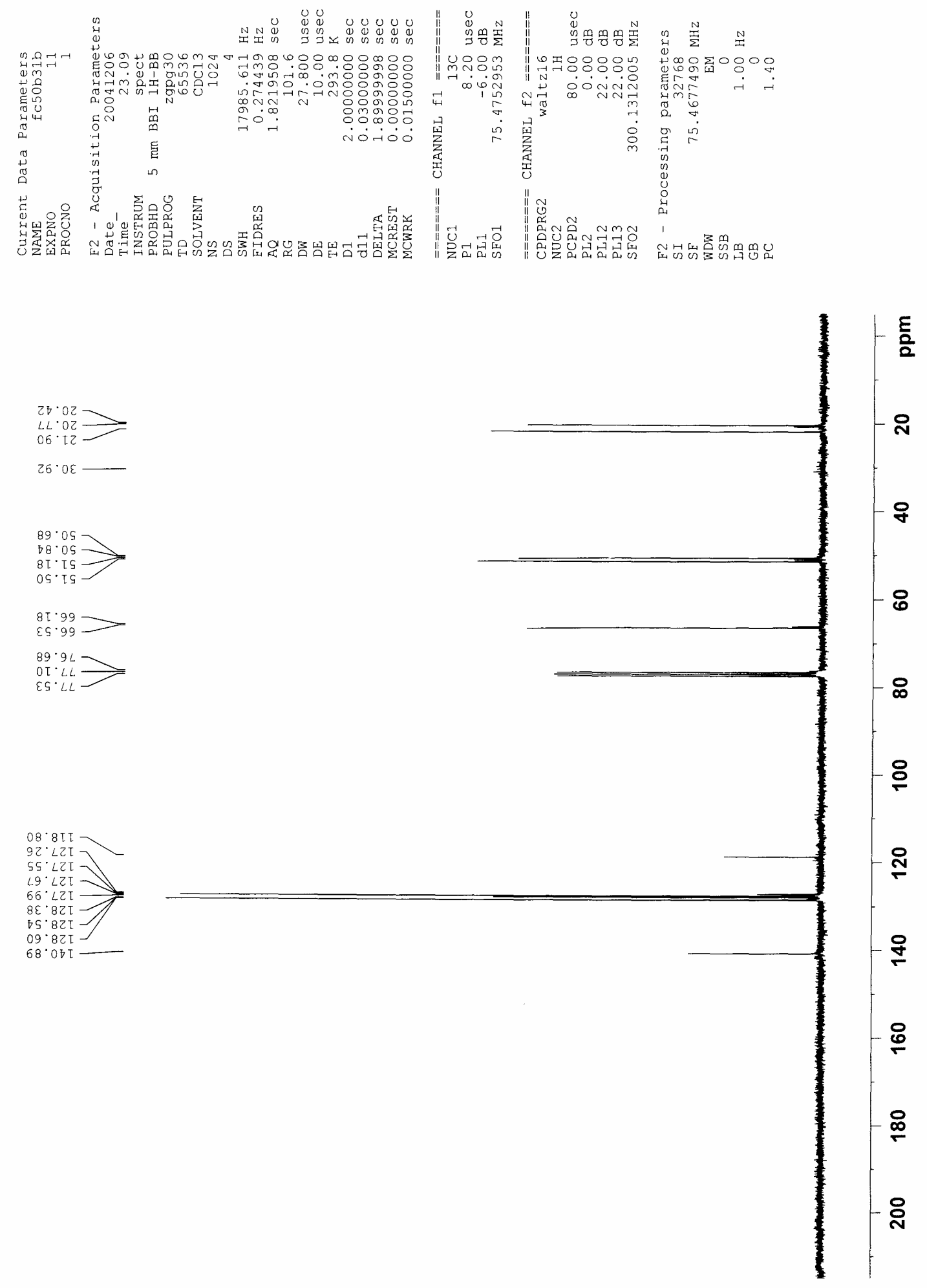

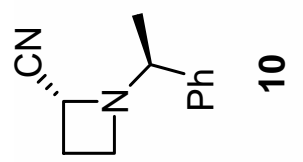



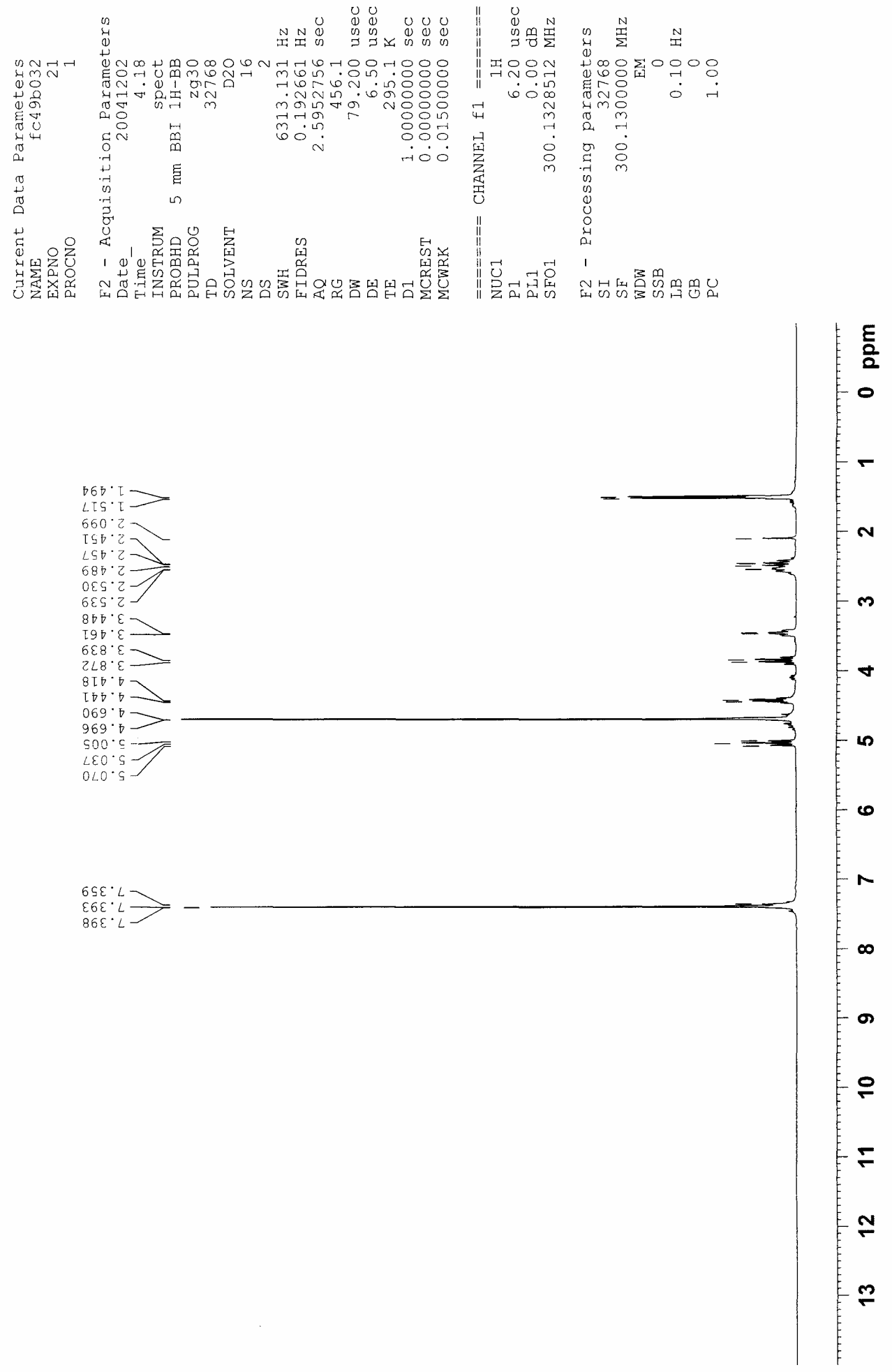

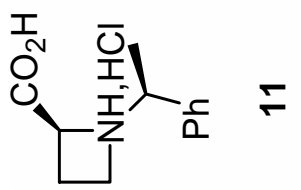



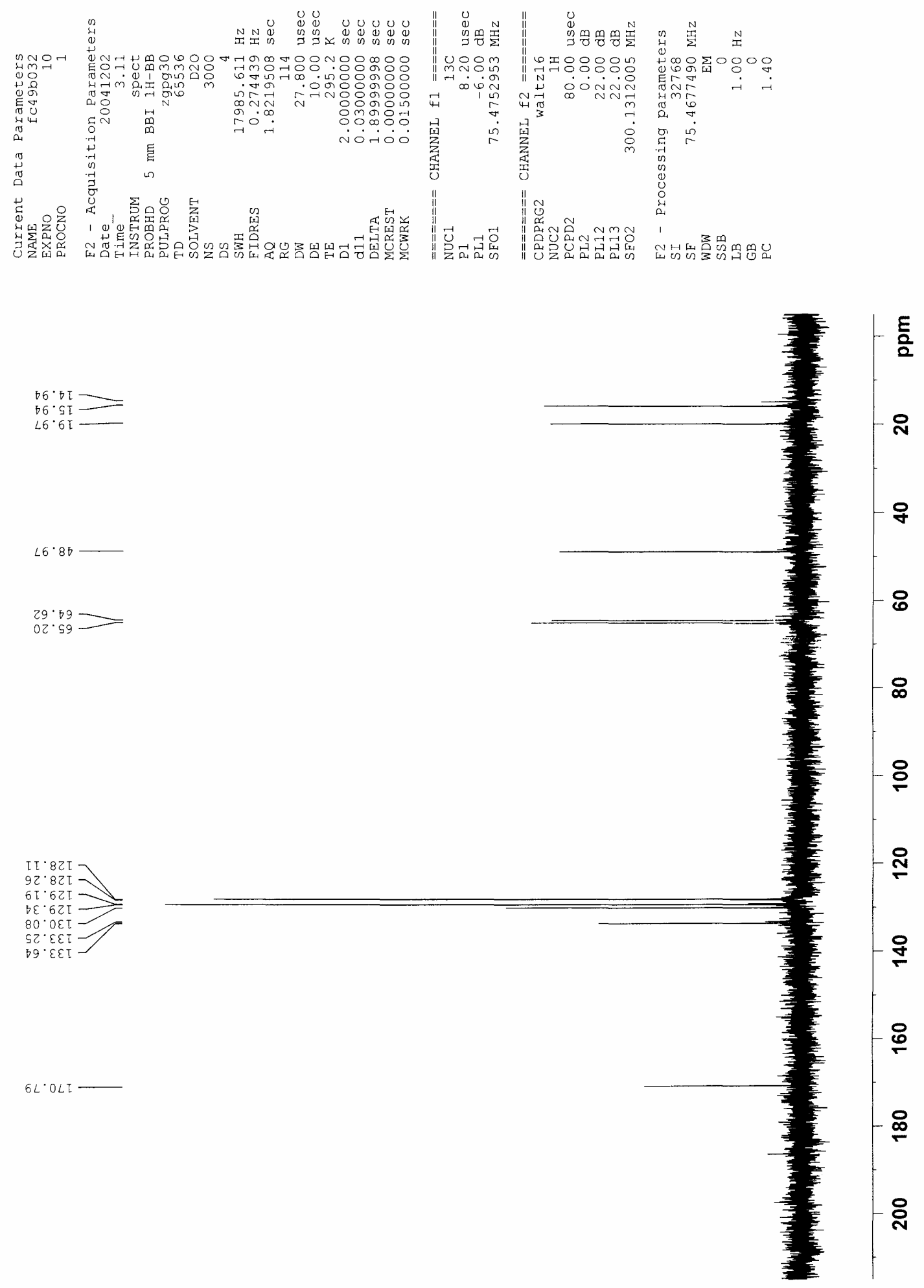

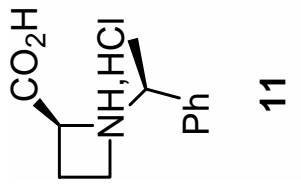




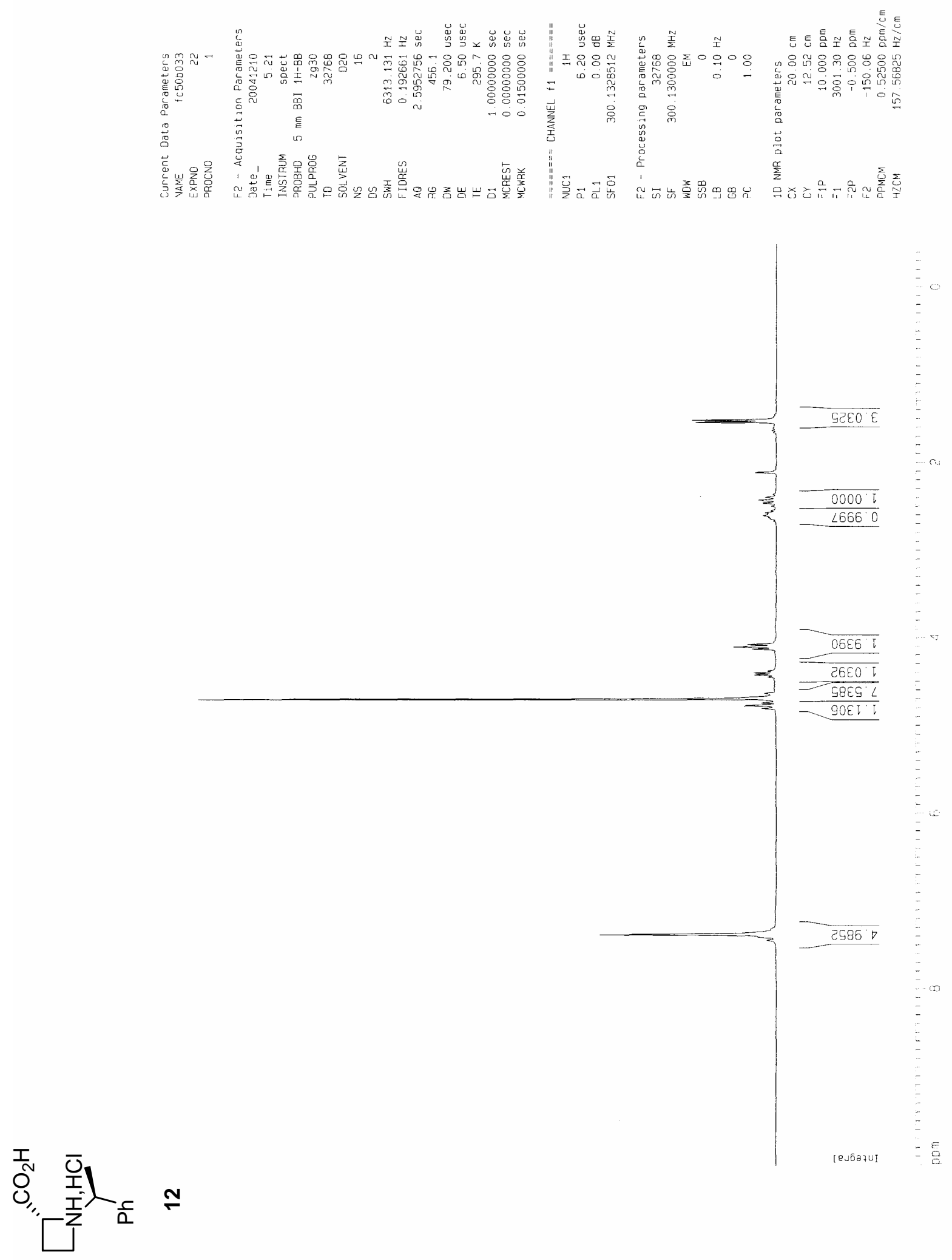



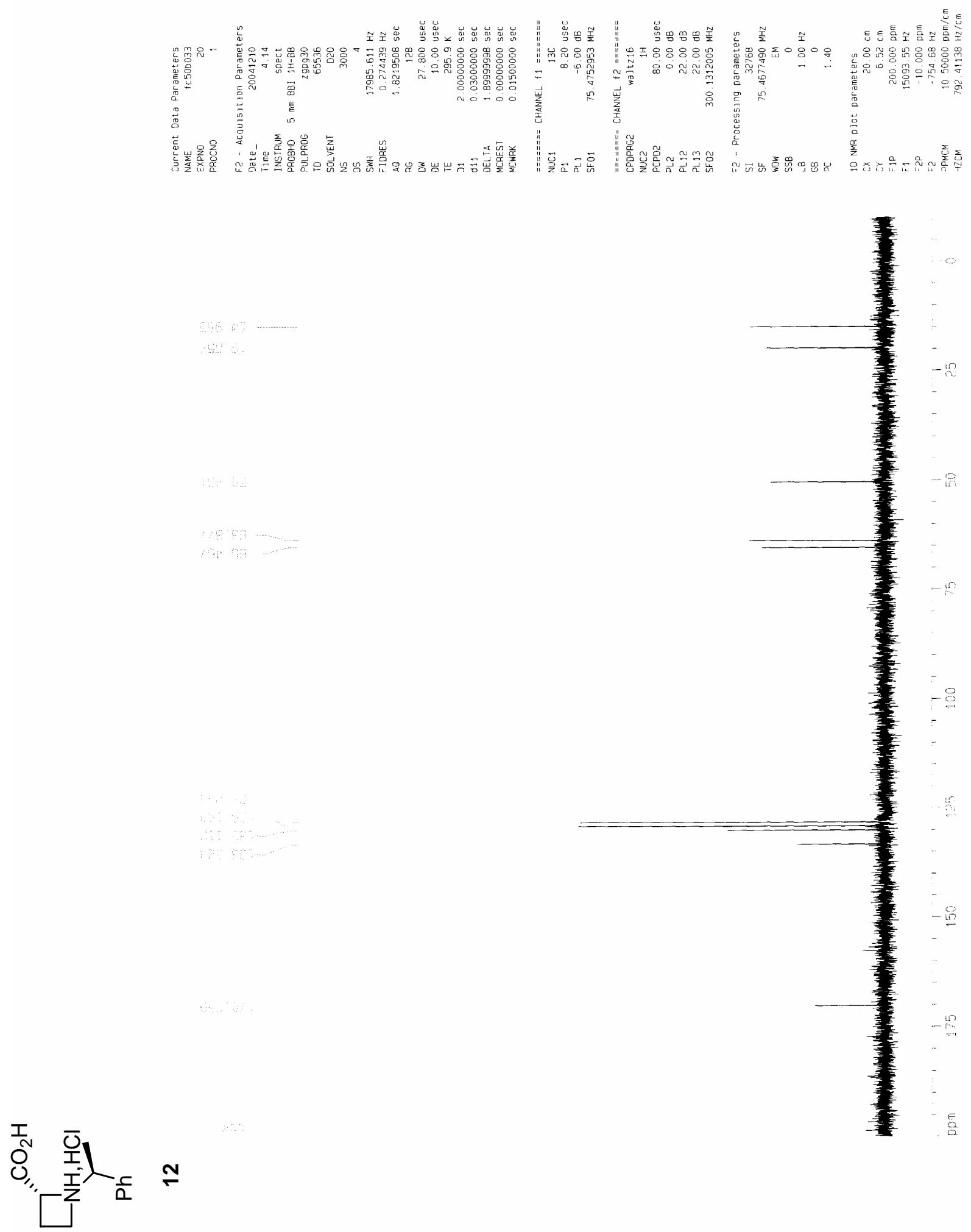

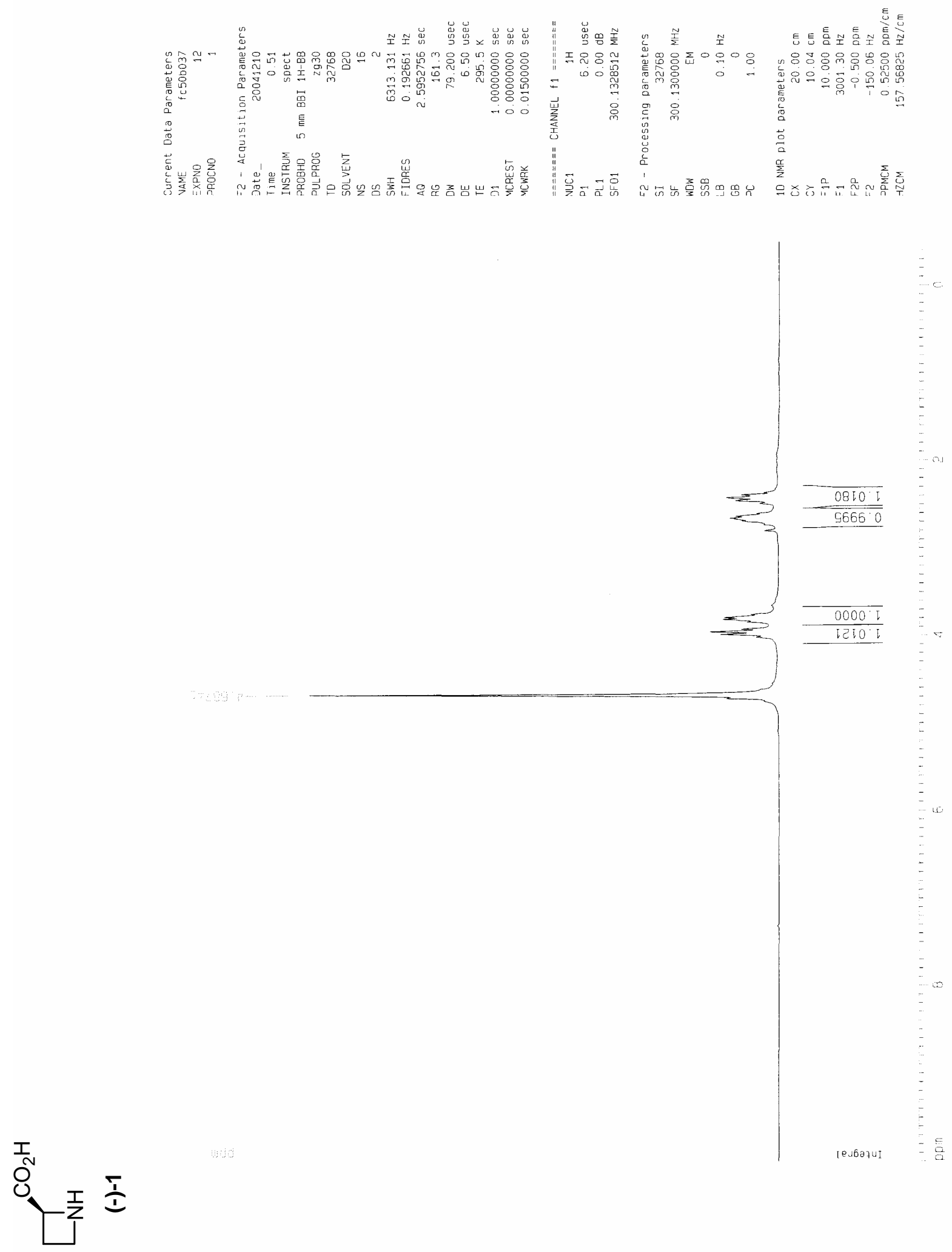


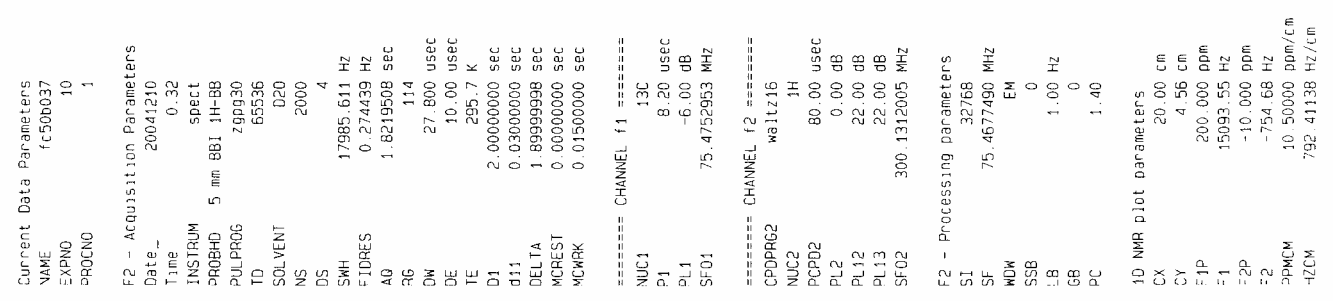

$\overbrace{\substack{I \\ O^{I}}}^{\frac{1}{I}}$

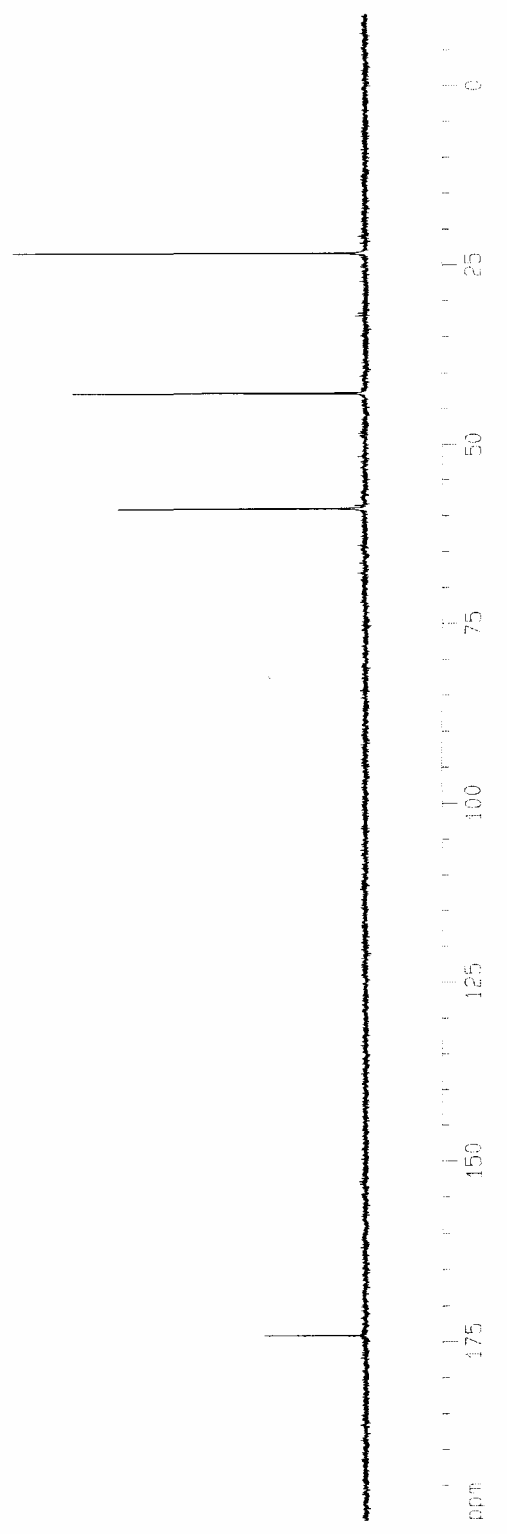




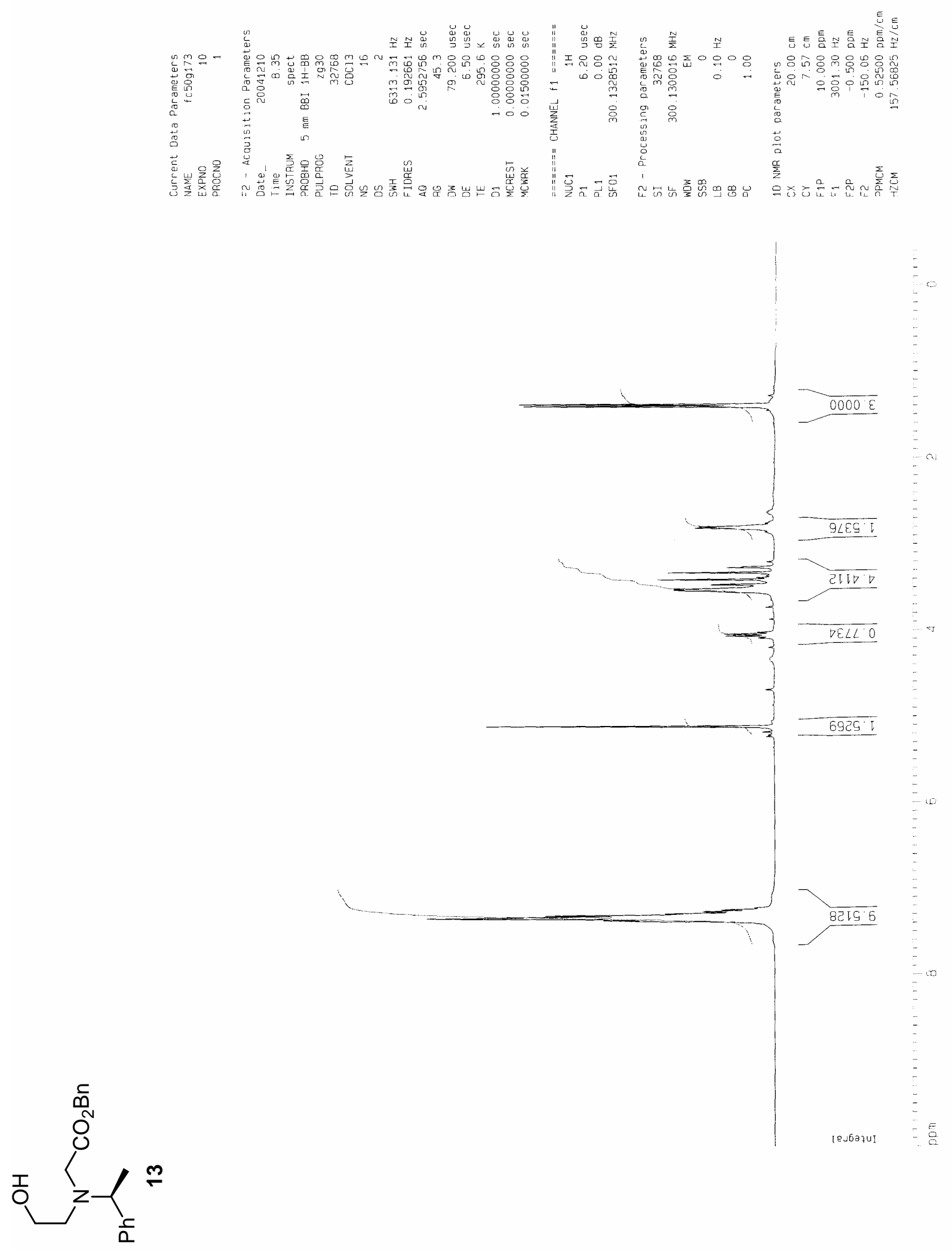



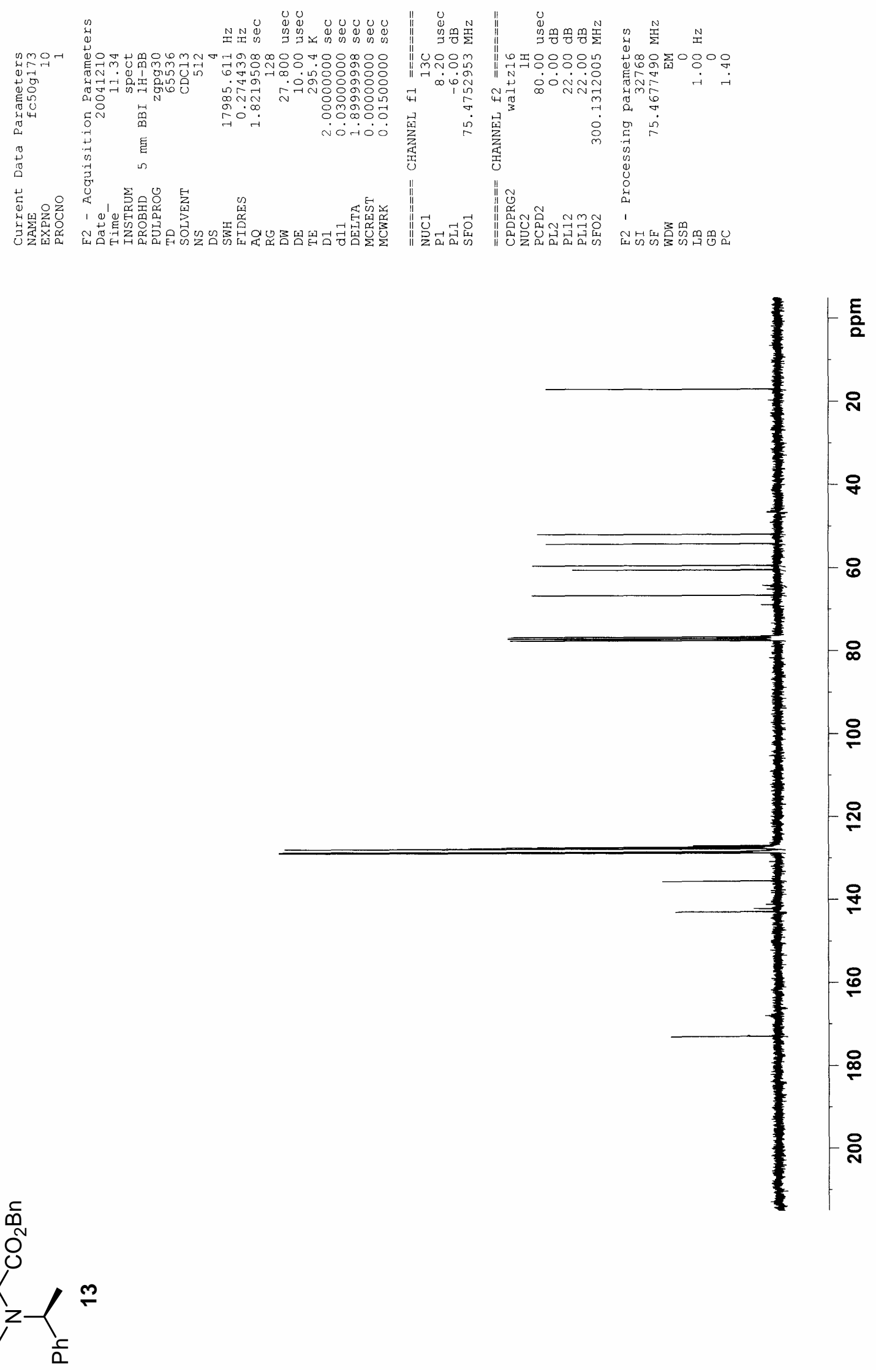

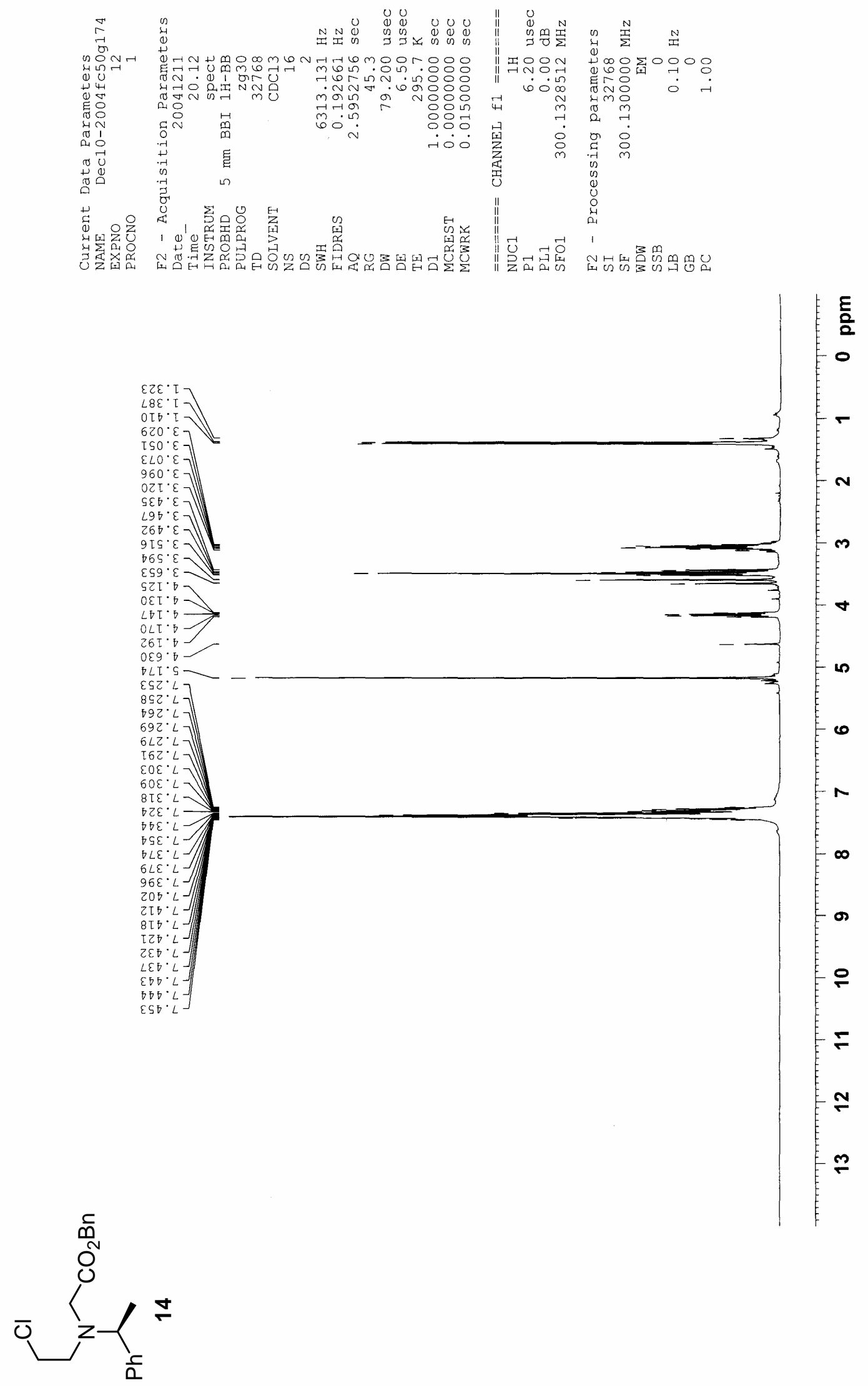

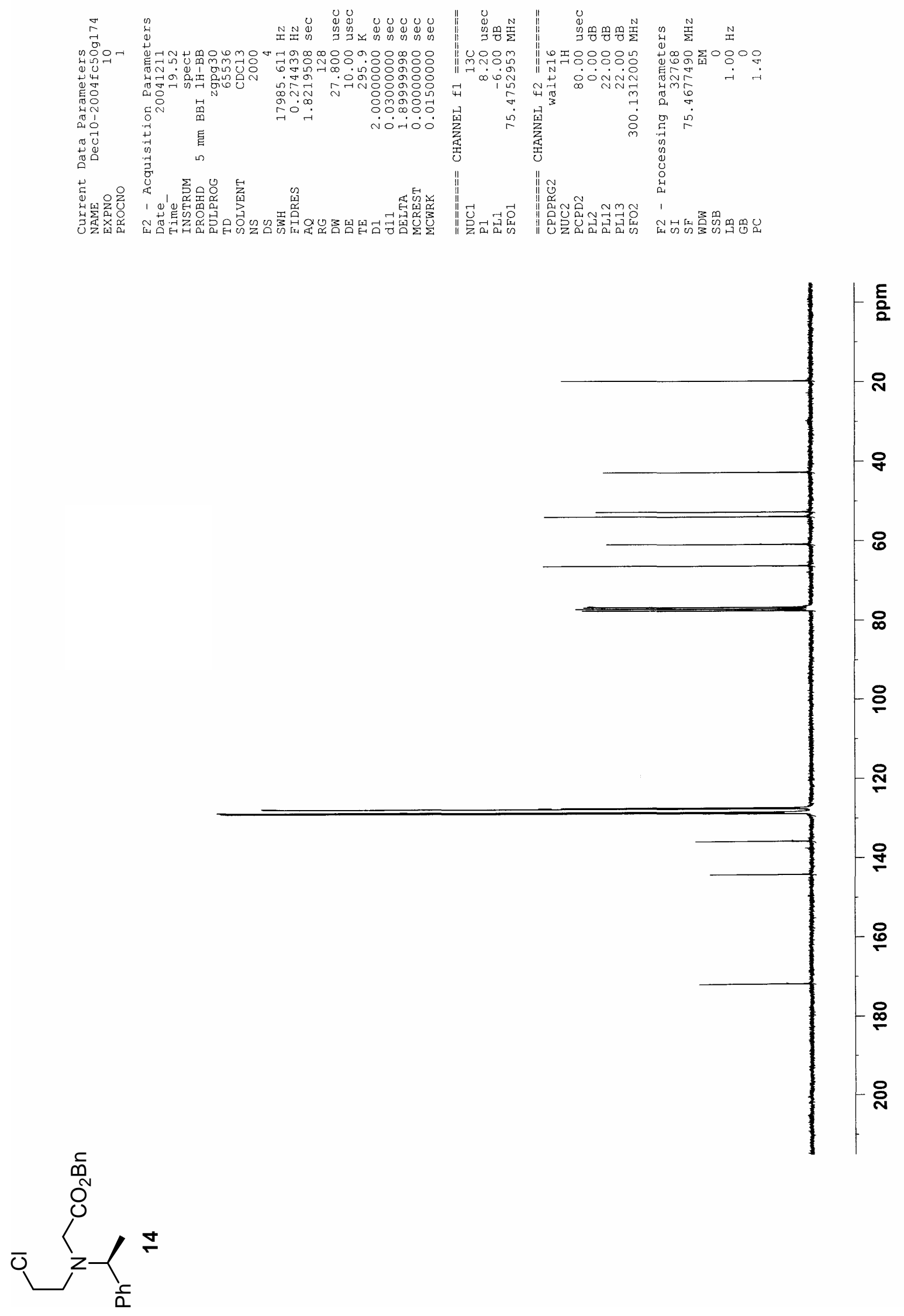

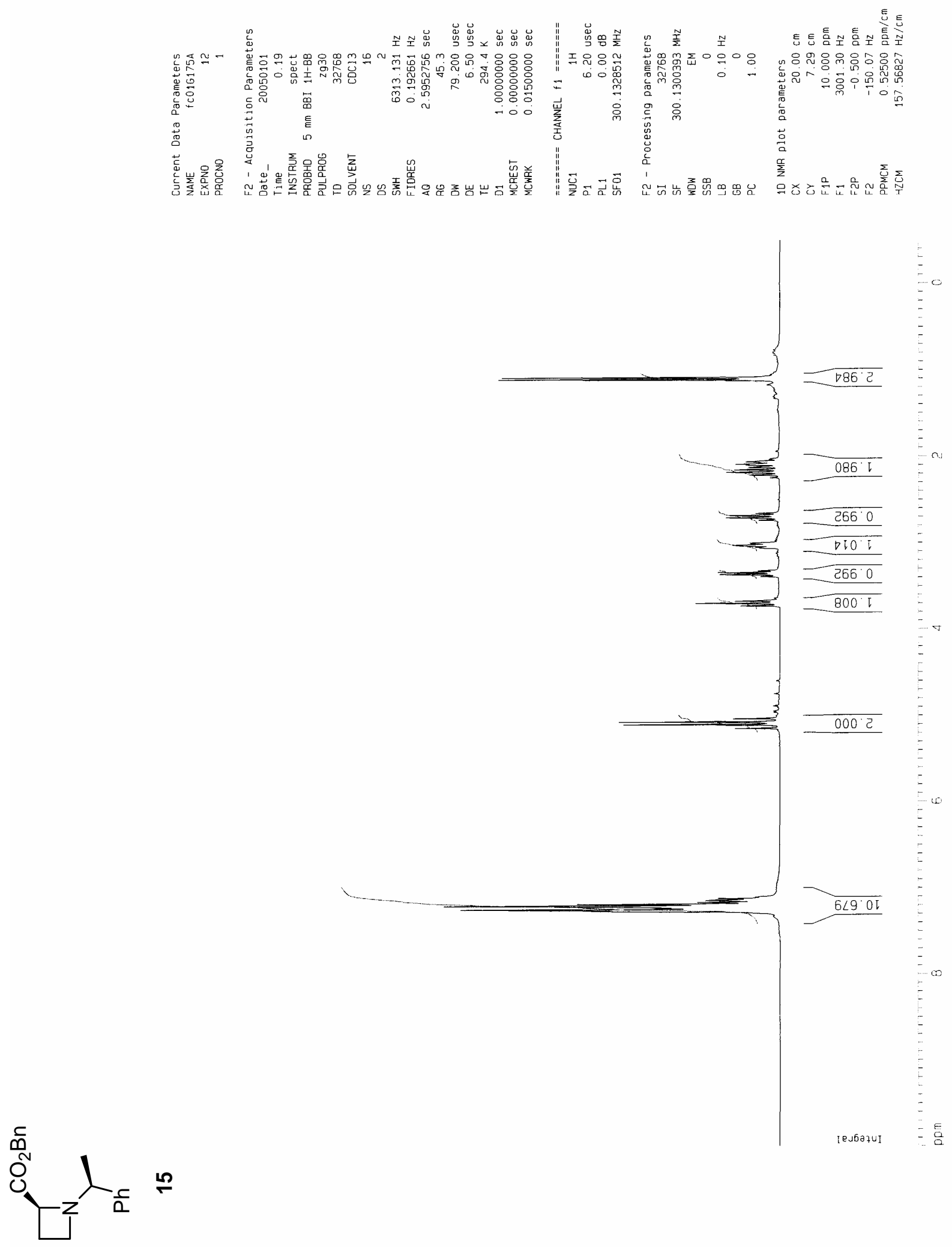


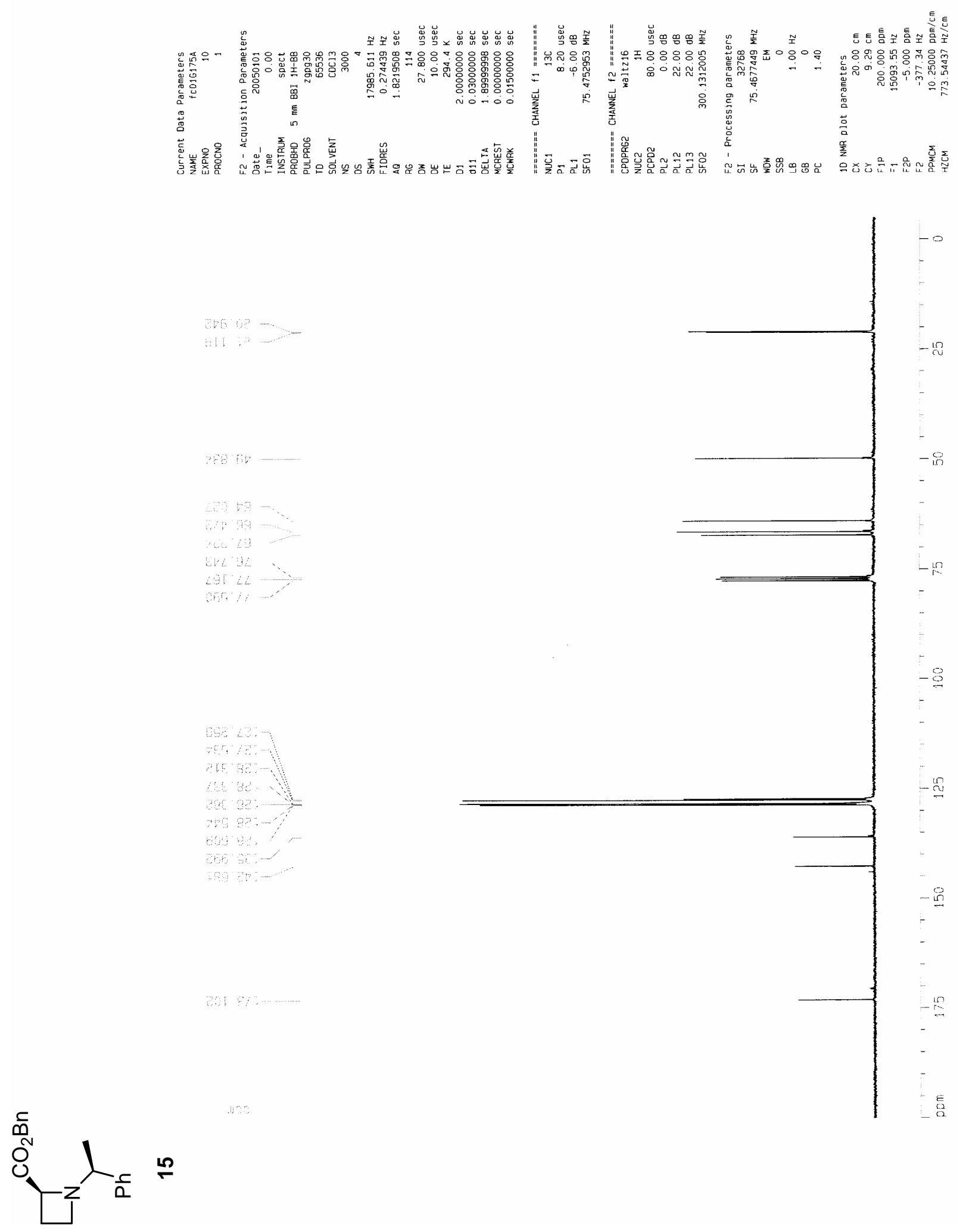



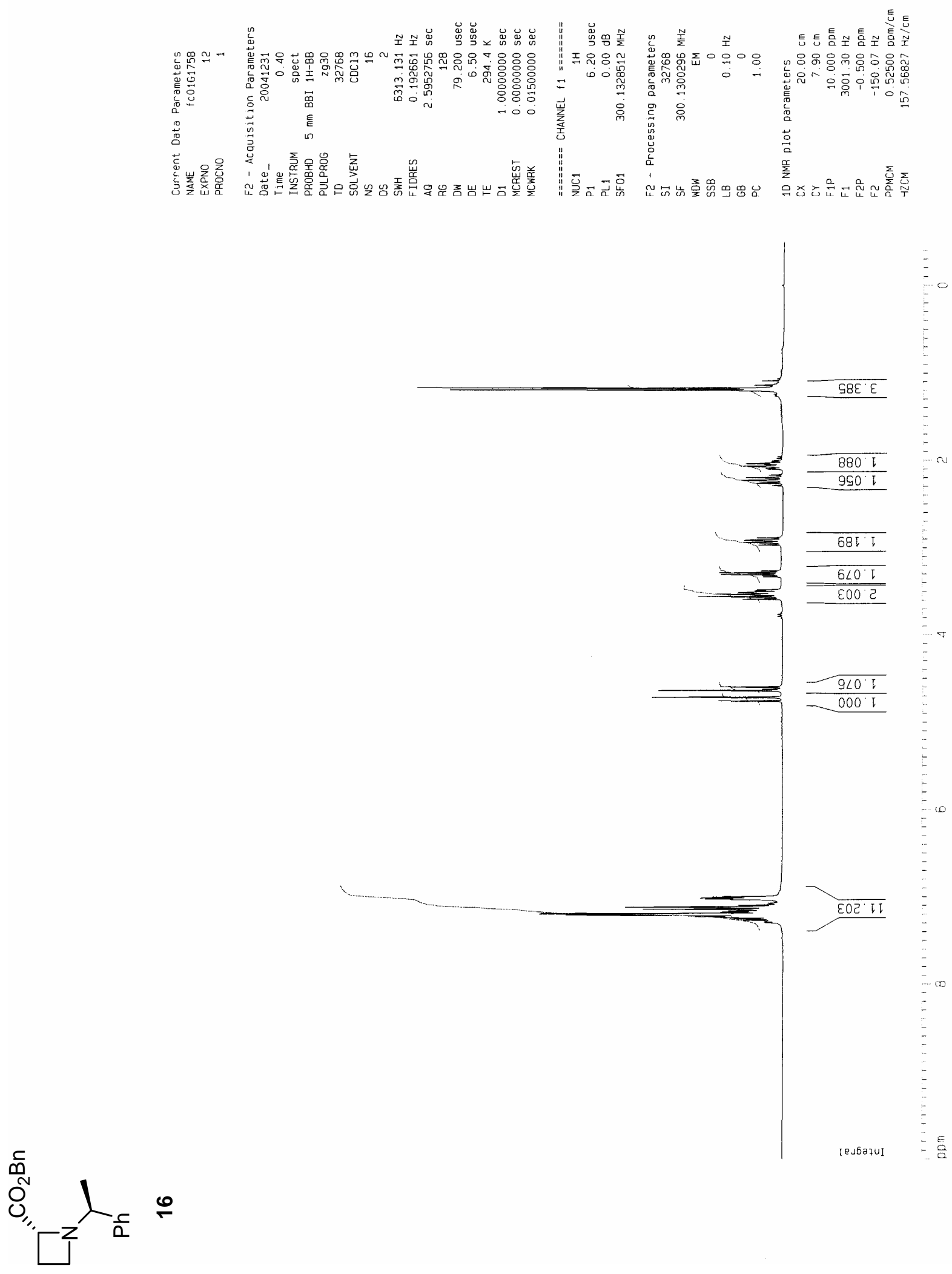

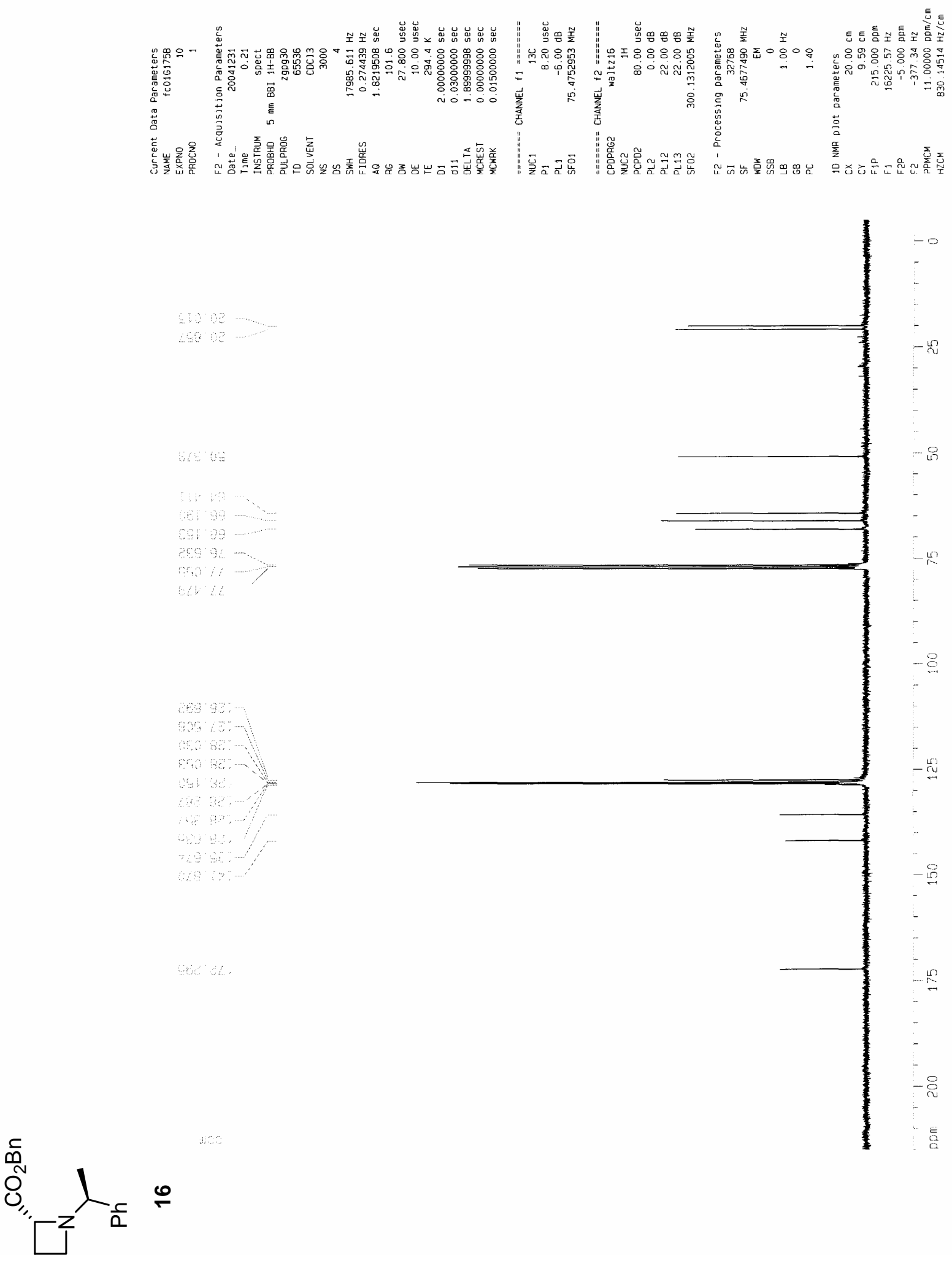